ORIGINAL ARTICLE / ARTIGO ORIGINAL

\title{
Factors associated with injuries in adolescents, from the National Adolescent School-based Health Survey (PeNSE 2012)
}

\author{
Fatores associados aos ferimentos em adolescentes, a partir da Pesquisa \\ Nacional de Saúde dos Escolares (PeNSE 2012)
}

\author{
Deborah Carvalho Malta',", Rogério Ruscitto do Prado, "II, Silvania Suely Andrade Caribel, \\ Marta Maria Alves da Silva', Marco Antonio Ratzsch de Andreazziv, Jarbas Barbosa da Silva Júnior", \\ Maria Cecilia de Souza Minayovl
}

\begin{abstract}
Objective: To estimate the prevalence of injuries among teenagers and to examine the associated risk factors, such as sociodemographic characteristics, risk behaviors, family ties and other factors. Method: The prevalence of the outcome (injury) was estimated with a $95 \%$ confidence interval. In order to verify factors associated with the injury, a bivariate analysis was made with estimated odds ratio (OR) and its respective confidence intervals. Then, a multivariate analysis was carried out, only with variables whose descriptive level was equal to or lower than $5 \%$ $(\mathrm{p}<0.05)$ remaining in the model. Results: The study of injury in adolescents, based on the data from the National Adolescent School-based Health Survey (PeNSE), pointed out that $10.3 \%$ of the teenagers suffered severe injuries in the past 12 months, such as cuts or perforations, broken bones or dislocated joints. The following variables remained independently associated with "suffering severe injuries": being a male teenager; black, mulatto or indigenous race/color and working. Factors related to family ties are significant when the relations are fragile amongst members: adolescents that are injured the most are the ones who suffer most aggressions at home, who skip classes without notifying their parents, those who do not live with their parents and have low family control. The most relevant aspects of mental health are insomnia and loneliness. The factors associated to the exposure to situations of violence that remained in the model were: insecurity in school and in the route home-school; getting a ride with someone inebriated; drinking and driving motorized vehicles; not wearing the seatbelt; not wearing a helmet and being bullied. Among the factors of individual behavior, the following can be emphasized: use of alcohol, cigarettes, trying illicit drugs and early sexual intercourse. Conclusion: The analysis of the determinants for suffering injuries in childhood and adolescence shows the complex relationship between associated factors, which points to the need for action towards several aspects to reduce social inequalities, strengthen family ties and prevent violent contexts and individual risk factors.
\end{abstract}

Keywords: Adolescent. Violence. Injuries. Alcoholic beverages. Smoking. Mental health.

'Department of Non-Communicable Diseases Surveillance and Health Promotion, Health Surveillance Secretariat, Ministry of Health - Brasília (DF), Brazil.

"Universidade Federal de Minas Gerais - Belo Horizonte (MG), Brazil.

"'Universidade de São Paulo - São Paulo (SP), Brazil.

"vrazilian Institute of Geography and Statistics - Rio de Janeiro (RJ), Brazil

vHealth Surveillance Secretariat, Ministry of Health - Brasília (DF), Brazil.

v'Latin-American Center of Violence and Health Studies at the National School of Public Health of Fundação Oswaldo Cruz Rio de Janeiro (RJ), Brazil.

Corresponding author: Deborah Carvalho Malta. Departamento de Vigilância de Doenças e Agravos Não-Transmissíveis e Promoção da Saúde, Secretaria de Vigilância em Saúde, Ministério da Saúde. SAF Sul, Trecho 02, Lotes 05 e 06 , Bloco F, Torre I, Edifício Premium, Térreo, Sala 14, CEP: 70070-600, Brasília, DF, Brasil. E-mail: deborah.malta@saude.gov.br

Conflict of interests: nothing to declare - Financing source: none. 
RESUMO: Objetivo: Estimar a prevalência de ferimentos entre adolescentes, e examinar os fatores associados aos mesmos, como características sócio-demográficas, comportamentos de risco, relações familiares e outros fatores. Método: Foi estimada a prevalência do desfecho (ferimento) com intervalo de confiança de $95 \%$. Para verificar fatores associados aos ferimentos, realizou-se análise bivariada com estimativas de razões de chance (OR) com seus respectivos intervalos de confiança, e realizada analise multivariada, permanecendo no modelo variáveis aquelas com nível descritivo igual ou inferior a 5\% ( $\mathrm{p}<0,05)$. Resultados: O estudo de ferimentos em adolescentes, feito a partir dos dados da Pesquisa Nacional de Saúde dos Escolares (PeNSE), apontou que 10,3\% dos adolescentes sofreram lesões graves nos últimos 12 meses, como cortes ou perfurações, ossos quebrados ou juntas deslocadas. Permaneceram independentemente associadas a "sofrer ferimentos graves" as variáveis: ser adolescente do sexo masculino; pertencer à raça/cor preta, parda, ou indígena e trabalhar. Fatores familiares têm força quando os laços são frágeis entre os membros: os adolescentes que mais se ferem são os que sofrem agressões em casa, faltam às aulas sem avisar aos pais, não moram com os pais e têm baixa supervisão familiar. Os aspectos mais relevantes da saúde mental são sofrer insônia e solidão. Os fatores associados à exposição a situações de violência que permaneceram no modelo foram: insegurança na escola e no trajeto casa-escola; ser conduzido por alguém alcoolizado; dirigir veículo motorizado; não usar cinto de segurança; não usar capacete na moto e sofrer bullying. Dentre os fatores de risco de comportamento individual, destacam-se: uso de álcool; uso de cigarro; experimentação de drogas ilícitas e ter relação sexual precoce. Conclusão: A análise dos fatores determinantes da ocorrência de ferimentos na infância e adolescência mostra a complexa relação dos fatores associados, apontando para a necessidade de atuação em várias frentes para a redução das desigualdades sociais, para o fortalecimento de laços familiares e para a prevenção dos contextos de violência e dos fatores de risco individuais.

Palavras-chave: Adolescente. Violência. Acidentes. Lesões. Bebidas alcoólicas. Tabagismo. Saúde mental.

\section{INTRODUCTION}

Injuries are the main cause of morbimortality among children and adolescents aged less than 18 years old - WHO estimates 875,000 deaths a years -, and they also affect the lives of about 30 million people due to wounds, inabilities and psychic disorders ${ }^{1}$. About $98 \%$ of the unintentional injuries in childhood occur in low and mid-income countries ${ }^{1,2}$.

Studies by the Global School and Health Survey indicated an annual prevalence of $41.3 \%$ related to injuries or wounds reported by adolescents aged between 11 and 15 years old, in the past 12 months, in 11 industrialized countries. This study also pointed out to great variation between countries ${ }^{3}$. Most studies indicates that unintentional injuries are more common among boys ${ }^{3-6}$.

In Brazil, in 2010, deaths caused by accidents and violence among children and adolescents aged 10 to 19 years old accounted for 16,232 deaths, rate of 47.5/100,000. Besides, they constituted the major magnitude events of victimization among adolescents in the country ${ }^{4}$. 
Analyses about external causes in adolescents who use morbidity or mortality data are the most frequent ones in Brazil ${ }^{5,7}$, therefore, it is important to make progress in the analysis of studies about the occurrence of injuries in the population scope.

Pickett et al. ${ }^{6}$ emphasize that the occurrence of aggravations in youth involves a complex interaction between several social, environmental, cultural and behavioral elements. The author also points out to the occurrence of association between several risk factors, or multiple risks, such as predictors of injuries/wounds. Literature indicates many factors associated with injuries among young people, such as: being male ${ }^{1,3-5}$, black or mulatto race / color $^{7}$, having low socioeconomic status ${ }^{6}$, living in violent and insecure environments ${ }^{3,6}$, reporting insecurity during the route home-school, school-home and inside the school environment ${ }^{8}$, and being bullied ${ }^{9}$. Individual risk behaviors are also described as the non-use of the seatbelt and helmet and the use of alcohol, cigarette and drugs ${ }^{6,10}$.

Other risk factors are also mentioned in studies concerning the behaviors of life as a family and the way parents and children relate, especially when they use violent communication and behavioral forms; when there is little parental control over their children's school and social life; when adolescents evade from school, relegate their school tasks and have low school performance; when they stay out of the house for long periods and do not notify their parents about their whereabouts in their free time $e^{6,11}$. A study also mentions other aspects associated with injuries, such as mental suffering, feelings of loneliness and isolation ${ }^{6}$. Literature also indicates that practicing sports can be a risk factor ${ }^{12}$.

Knowing the factors that are associated with injuries is important to encourage actions of health prevention and promotion in different contexts. In Brazil, these studies are still lacking. With the conduction of the II National Adolescent School-based Health Survey (PeNSE), in 2012, questions referring to injuries were introduced, which made it possible to analyze this feature among students ${ }^{13}$.

The objective of this study is to estimate the prevalence of injuries among adolescents, and to examine the factors that are associated to them, such as sociodemographic characteristics, risk behaviors, family ties and other factors.

\section{METHODS}

The National Adolescent School-based Health Survey (PeNSE), conducted in $2012^{13}$, investigated some risk behavior and health protection factors in a sample of students attending the $9^{\text {th }}$ grade of elementary school, during daytime, in public or private schools located in the urban or rural zones of a set of cities placed all over the Brazilian territory. This age group is comparable with the one in the study Global School and Health Survey, performed by the World Health Organization ${ }^{14}$. 
The register used for sampling selection was constituted of elementary schools listed in the School Census 2010, which informed having $9^{\text {th }}$ grade groups in daytime shifts. The sample estimated population parameters (prevalence) in several geographic domains: each of the 26 Brazilian State capitals and the Federal District, the set of these capitals, each one of the five major geographic regions and the country as a whole.

In the selected groups, there were 134,310 students enrolled in the $9^{\text {th }}$ grade of elementary school, in daytime shifts of schools located in urban or rural zones of the whole country. Out of these, 132,123 attended classes, 110,873 were present at the time of the study and 109,104 answered the study questionnaire (83\% of those who attended classes). About $90 \%$ of the students were between 13 and 15 years old, being $52 \%$ female and $48 \%$ male participants ${ }^{13}$.

The cluster sampling process was used, and the sampling plan was formed by schools (primary units) and classrooms (secondary units). Outside the capitals, primary units were made of groups of cities; secondary units, of schools; and classrooms consisted of the tertiary sampling units.

\section{STUDIED OUTCOME}

The studied outcome, "having suffered a serious injury in the past 12 months" was extracted from the question: "in the past 12 months, how many times were you seriously injured?", being categorized into: "No, not even once", and "Yes, once or more".

In order to better explore the severity of the injury, additional questions were asked to those who were injured - About the type of wound or injury: "in the past 12 months, which was the most serious wound/injury that affected you?" The options of answers were: broken bone or dislocated joint; cut or perforation; trauma or another lesion on the head or neck; fainting; difficulty breathing; severe burning; lesion or bruise. About the cause of wound or injury: "in the past 12 months, which was the main cause of wound/injury that affected you?" The options of answers were: accident or being hit by a motorized vehicle; falls; something fell on the person; being attacked; fighting with someone; fire or something hot; inhaling something; having swallowed something that made you feel bad; and others.

\section{EXPLANATORY VARIABLES}

The association model between wounds or serious injuries in the past 12 months is expressed in Figure 1. The model was proposed by the authors and is based on evidence in literature $^{3-12}$ that points out to multiple determinations associated with the occurrence of wounds / injuries in children and adolescents, which include sociodemographic, environmental, 
cultural and behavioral elements ${ }^{5-12}$. In this case, analyses including several explanatory variables were performed, and they can be grouped into:

1. Sociodemographic aspects:

- gender, age, race/color, maternal schooling, type of school; work among adolescents.

2. Individual risk or protective factors:

- Regular use of tobacco in the past 30 days (how many days did you smoke cigarrettes?”);

- Regular alcohol consumption in the past 30 days ("have you had at least one dose of alcohol?", and options of answers were "No, not even once" and "Yes, once or more");

- Trying illicit drugs ("have you ever tried drugs, such as: marijuana, cocaine, crack, solvent-based glue, narcotic made of chloroform and ether, popper, ecstasy, oxy, among others?", and options of answers were "No, never", and "Yes, once or more");

- Having had sexual intercourse ("have you ever had sexual intercourse?", with options "Yes" and "No");

- Practicing physical activity ("in the past 7 days, how often have you practised physical activities for 60 minutes / day?", with options "Yes" for those who answered 5 days and more and "No" for those who answered 4 days and less).

3. Factors related to mental health:

- Feeling lonely ("in the past 12 months, how often have you felt lonely?", being the options of answers "Never or sometimes" and "Yes: most of the time or always");

- Having insomnia ("in the past 12 months, how often could you not sleep at night because something was on your mind?", with the options "No: no and sometimes" and "Yes: most of the time and always");

- Having close friends or living isolated ("how many friends do you have?", with options "No" and "yes: one, two and more friends").

4. Family context:

- Living with mother and/or father ("do you live with your mother? Do you live with your father?", with the options "Yes: living with father and/or mother" and "No: not living with father or mother");

- Having family supervision (in the past 30 days, how often did your parents or people in charge know what you were really doing in your free time?", with options "Yes: most of the time and always" and "No: never, rarely and sometimes"); Missing classes without permission ("in the past 30 days, how often did you miss classes or school without parental permission?", with options "Yes, from one to 10 days" and "No"); 
- Being assaulted and being beaten by family members ("in the past 30 days, how often were you physically assaulted by an adult in your family?" with options "No: never" and "Yes, once, twice, three times or more").

5. Contextual violence factors:

- Insecurity in the route home-school and school-home, by combining the answers of two questions ("in the past 30 days, how often did you not go to school because you did not feel safe in the route?");

- Insecurity in school ("in the past 30 days, how often did you miss school for not feeling safe in this environment?");

- Being bullied (in the past 30 days, how often did any of your school colleagues ridicule, mocked, made fun, intimidate or teased you and made you feel hurt/ upset/annoyed/offended/humiliated?", with the options "No: never, rarely, sometimes" and "Yes: most of the time, or always");

- Using a seatbelt ("in the past 30 days, how often did you use a seatbelt in a car or another motorized vehicle driven by someone else?", with the options "No: never, rarely and sometimes" and "Yes: always"). Individuals who claimed to not ride vehicles were excluded;

- Wearing a helmet on the motorcycle ("in the past 30 days, how often did you wear a healmet to ride a motorcycle?", with the options "No: not once, rarely, most of the time" and "Yes: always"). Individuals who claimed to not ride motorcycles were excluded;

- Driving a motorized vehicle in the past thirty days ("how often did you drive a motorized vehicle: car, motorcycle, bass boat, bot and others?", with options "No, I did not drive one" and "Yes, once or more");

- Being conducted by an inebriated person ("in the past 30 days, how often were you in a car or another motorized vehicle driven by someone who had consumed any alcoholic drinks?", with options "No, never" and "Yes, once or more").

At first, there was an estimate of the outcome prevalence (injury), with $95 \%$ confidence interval $(95 \% \mathrm{CI})$, as well as the description of the type of injury.

In order to verify factors associated with the injuries, a bivariate analysis was conducted with odds ratio (OR) estimates and the respective confidence intervals. Subsequently, all of the variables of interest were inserted in the multivariate model, and those with descriptive level equal to or lower than $5 \%(\mathrm{p}<0.05)$ and with epidemiological base remained; statistically significant variables remained in the final adjusted model $(\mathrm{p}<0.05)$.

In order to correct the different selection probabilities of each student, weights were used to estimate proportions. The analysis was conducted with the software SPSS, version 
20, using procedures from the Complex Samples Module, which is adequate to analyze data obtained by the complex sampling plan.

The study that originated this article was approved by the Research Ethics Committee of the Ministry of Health, report n. 192/2012, registration n. 16805 of CONEP/MS, on $27 / 03 / 2012$.

Block 1 - Sociodemographic aspects

Being seriously injuried

Block 2 - Individual risk and/or protective factor

Block 3 - Mental health

Block 4 - Family context

Block 5 - Contextual violence factor
Feeling lonely Having insomnia Having close friends

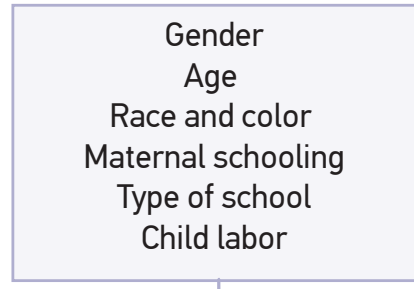

Cigarette Alcohol

Drugs

Sexual intercourse

Recommended physical activity

Living with mother and/or father

Family supervisionduring free time Missing classes without notifying parents Being assaulted by Family members

Insecurity in the route home-school

Being bullied

Wearing a seatbelt

Wearing a helmet on a motorcycle

Driving a motorized vehicle

Being conducted by an inebriated person

Figure 1. Hierarchical model proposed to determine the occurrence of serious injuries in Brazilian school-aged adolescents, National Adolescent School-based Health Survey (PeNSE), Brazil, 2012. 


\section{RESULTS}

Out of the adolescents who composed the sample, $10.3 \%$ reported having suffered serious injuries in the past 12 months. Out of these, $6.8 \%$ suffered only one wound, $2 \%$ had repeated events, from two to three times, and $1.5 \%$, four or more times (Table 1 ).

The injuries that less serious or medium, wound or bruise and cut or perforation, were the most reported ones by adolescents. Afterwards came the more severe injuries, such as broken bone or dislocated joint. Lower frequencies, below 4\%, were burns, traumas or other injuries on the head and neck, with fainting/difficulty breathing. Among the causes of injuries, the most mentioned one was falling (44\%), followed by other unspecified reasons (about one third). The other causes, like being hit by an object, being attacked or participating in a fight, suffering an accident or being hit by a motorized vehicle, occurred in less than $10 \%$ of the cases.

The analysis according to sociodemographic factors showed that injuries were most common among male students, increasing with age, in black, mulatto, indigenous adolescents, children of mothers with no schooling, who attend public schools and work (Table 2).

Among individual risk behaviors, adolescents who used tobacco, illicit drugs, alcohol or those who had sexual intercourse were associated with injuries. Variables corresponding to health domain were associated with injuries: report of insomnia, loneliness, not having friends. The following situations of exposure to violent situations and accidents were also associated with injuries: feeling insecure at school, feeling insecure in the route home-school, being bullied, being conducted by an inebriated person, driving a motorized vehicle, not wearing a seatbelt and not wearing a helmet on the motorcycle (Table 3 ).

The family context factors associated with injuries were: assault from Family members, missing school without notifying the parents and not living with father and/or mother. Protective factors were demonstrated by adolescents who reported family supervision, or the fact that parents and people in charge knew about the adolescents' whereabouts during their free time (Table 3 ).

In the final model, the following variables remained independently associated with being severely injured: being male, black, mulatto and indigenous, and working, besides individual risk factors, such as the use of alcohol, cigarettes, trying drugs and having early sexual intercourse. Physical activity lost statistical significance in the final model. As to mental health, the variables having insomnia and feeling lonely remained associated; in the family context, being assaulted by family members, missing classes without notifying the parents and not living with father and mother were associated. Family supervision proved to be a protective factor. Factors associated with exposure to violent situations were: feeling insecure in school and in the route home-school, being conducted by an inebriated person, driving a motorized vehicle, not wearing a seatbelt, not wearing a helmet when riding a motorcycle and being bullied (Table 4). 
Table 1. Prevalence of occurrence, type and cause of injuries, by gender, in school-aged adolescents, National Adolescent School-based Health Survey, Brazil, 2012.

\begin{tabular}{l|c|c|c|c|c|c|}
\multirow{2}{*}{ Indicator } & \multicolumn{2}{|c|}{ Total } & \multicolumn{4}{c|}{ Gender } \\
\cline { 4 - 8 } & \multicolumn{2}{|c|}{} & \multicolumn{3}{|c|}{ Male } & \multicolumn{2}{c|}{ Female } \\
\cline { 2 - 8 } & $\%$ & $\mathrm{Cl}(95 \%)$ & $\%$ & $\mathrm{Cl}(95 \%)$ & $\%$ & $\mathrm{Cl}(95 \%)$ \\
\hline
\end{tabular}

Being seriously injuried

\begin{tabular}{|c|c|c|c|c|c|c|c|c|c|}
\hline Never & 89.7 & 89.6 & 89.9 & 88.2 & 88.0 & 88.5 & 91.1 & 90.8 & 91.4 \\
\hline Once & 6.8 & 6.6 & 6.9 & 7.4 & 7.2 & 7.7 & 6.2 & 5.9 & 6.5 \\
\hline Two or three times & 2.0 & 1.9 & 2.1 & 2.3 & 2.2 & 2.5 & 1.7 & 1.6 & 1.9 \\
\hline Four times or more & 1.5 & 1.4 & 1.5 & 2.0 & 1.8 & 2.1 & 1.0 & 0.9 & 1.1 \\
\hline \multicolumn{10}{|l|}{ Type of injury* } \\
\hline $\begin{array}{l}\text { Broken bone or } \\
\text { dislocated joint }\end{array}$ & 18.7 & 18.2 & 19.3 & 21.2 & 20.5 & 22.0 & 15.6 & 14.7 & 16.6 \\
\hline Cut or perforation & 30.6 & 30.0 & 31.2 & 33.1 & 32.3 & 34.0 & 27.4 & 26.2 & 28.6 \\
\hline $\begin{array}{l}\text { Trauma or another lesion on } \\
\text { the head or neck and fainting } \\
\text { or could not breathe }\end{array}$ & 2.0 & 1.8 & 2.2 & 1.9 & 1.7 & 2.2 & 2.1 & 1.8 & 2.6 \\
\hline Severe burning & 3.9 & 3.7 & 4.2 & 2.4 & 2.1 & 2.7 & 5.8 & 5.1 & 6.7 \\
\hline Injury or wound & 44.7 & 44.1 & 45.4 & 41.3 & 40.4 & 42.2 & 49.0 & 47.7 & 50.4 \\
\hline
\end{tabular}

Cause of injury*

\begin{tabular}{l|c|c|c|c|c|c|c|c|c}
\hline $\begin{array}{l}\text { Accident or being hit by a } \\
\text { motorized vehicle }\end{array}$ & 6.3 & 5.9 & 6.6 & 7.2 & 6.7 & 7.7 & 5.1 & 4.6 & 5.7 \\
\hline $\begin{array}{l}\text { Falls } \\
\begin{array}{l}\text { Something fell on me } \\
\text { or hit me }\end{array}\end{array}$ & 44.0 & 43.3 & 44.7 & 46.2 & 45.3 & 47.2 & 41.2 & 39.9 & 42.6 \\
\hline $\begin{array}{l}\text { Suffered attack or got in a } \\
\text { fight with someone }\end{array}$ & 6.5 & 6.2 & 6.8 & 6.6 & 6.2 & 7.1 & 6.3 & 5.7 & 7.0 \\
\hline $\begin{array}{l}\text { Fire or proximity with } \\
\text { something hot }\end{array}$ & 1.3 & 1.2 & 1.5 & 1.3 & 1.1 & 1.6 & 1.4 & 1.1 & 1.7 \\
\hline $\begin{array}{l}\text { Inhaling or swallowing } \\
\text { something that made me } \\
\text { feel bad }\end{array}$ & 0.9 & 0.8 & 1.0 & 0.8 & 0.7 & 1.0 & 1.0 & 0.8 & 1.3 \\
\hline $\begin{array}{l}\text { Another cause } \\
\text { fund }\end{array}$ & 33.0 & 32.4 & 33.7 & 31.3 & 30.4 & 32.1 & 35.2 & 33.9 & 36.5 \\
\hline
\end{tabular}

*Only students who have suffered injury. 
Table 2. Frequency of occurrence of serious injuries in the last 12 months ( $\%$ and $95 \% \mathrm{Cl})$ among Brazilian 9th graders, according to socioeconomic and demographic characteristics, 2012.

\begin{tabular}{|c|c|c|c|c|c|c|c|}
\hline \multirow{3}{*}{ Variable } & \multicolumn{6}{|c|}{ Serious injury } & \multirow{3}{*}{ p-value } \\
\hline & \multirow{2}{*}{$\%$} & \multicolumn{2}{|c|}{$95 \% \mathrm{Cl}$} & \multirow{2}{*}{ OR } & \multicolumn{2}{|c|}{$95 \% \mathrm{Cl}$} & \\
\hline & & Inferior & Superior & & Inferior & Superior & \\
\hline Total & 10.3 & 10.1 & 10.4 & & & & \\
\hline \multicolumn{8}{|l|}{ Age (years) } \\
\hline$<13$ & 9.9 & 8.0 & 12.2 & 0.71 & 0.56 & 0.89 & 0.003 \\
\hline 13 & 8.4 & 7.9 & 8.9 & 0.59 & 0.55 & 0.63 & $<0.001$ \\
\hline 14 & 9.5 & 9.0 & 10.0 & 0.67 & 0.63 & 0.71 & $<0.001$ \\
\hline 15 & 12.2 & 11.5 & 12.9 & 0.89 & 0.83 & 0.94 & $<0.001$ \\
\hline 16 and more & 13.5 & 13.0 & 14.1 & 1.00 & & & \\
\hline \multicolumn{8}{|l|}{ Gender } \\
\hline Male & 11.8 & 11.4 & 12.2 & 1.36 & 1.31 & 1.42 & $<0.001$ \\
\hline Female & 8.9 & 8.7 & 9.1 & 1.00 & & & \\
\hline \multicolumn{8}{|l|}{ Race } \\
\hline White & 9.5 & 9.2 & 9.8 & 1.00 & & & \\
\hline Black & 11.9 & 11.3 & 12.6 & 1.29 & 1.22 & 1.38 & $<0.001$ \\
\hline Mulatto & 11.2 & 10.3 & 12.3 & 1.21 & 1.10 & 1.34 & $<0.001$ \\
\hline Yellow & 10.1 & 9.7 & 10.5 & 1.08 & 1.03 & 1.13 & 0.001 \\
\hline Indigenous & 12.5 & 11.4 & 13.7 & 1.37 & 1.23 & 1.51 & $<0.001$ \\
\hline \multicolumn{8}{|c|}{ Maternal schooling } \\
\hline No schooling & 12.5 & 11.5 & 13.5 & 1.22 & 1.11 & 1.33 & $<0.001$ \\
\hline $\begin{array}{l}\text { Elementary } \\
\text { (incomplete/ } \\
\text { complete) }\end{array}$ & 10.1 & 9.4 & 10.8 & 0.96 & 0.89 & 1.03 & 0.255 \\
\hline $\begin{array}{l}\text { High School } \\
\text { (incomplete/ } \\
\text { complete) }\end{array}$ & 10.1 & 9.4 & 10.8 & 0.96 & 0.89 & 1.03 & 0.236 \\
\hline $\begin{array}{l}\text { Higher } \\
\text { education } \\
\text { (incomplete/ } \\
\text { complete) }\end{array}$ & 10.5 & 9.9 & 11.1 & 1.00 & & & \\
\hline \multicolumn{8}{|l|}{ School } \\
\hline Private & 8.8 & 8.4 & 9.3 & 1.00 & & & \\
\hline Public & 10.6 & 10.4 & 10.8 & 1.22 & 1.16 & 1.29 & $<0.001$ \\
\hline \multicolumn{8}{|c|}{ Currently working } \\
\hline No & 9.4 & 9.2 & 9.5 & 1.00 & & & \\
\hline Yes & 16.2 & 15.6 & 16.9 & 1.87 & 1.78 & 1.97 & $<0.001$ \\
\hline
\end{tabular}


Table 3. Prevalence, crude and adjusted OR of variables Mental Health, Family Context, Exposure to Situations with Risk of Violence and Accidents, and behavioral risk or protective factors (tobacco, alcohol, gender, physical activity) associated to the occurrence of serious injury (\% and $95 \mathrm{Cl} \%$ ) between Brazilian 9th graders, Brazil, 2012.

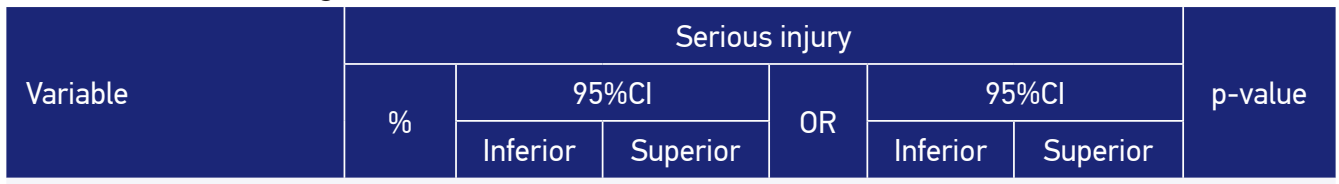

Contextual mental health factors

Feeling lonely

\begin{tabular}{l|c|c|c|c|c|c|c}
\hline \multicolumn{1}{|c|}{ No } & 9.2 & 9.0 & 9.4 & 1.00 & & & \\
\hline \multicolumn{1}{|c|}{ Yes } & 15.6 & 15.0 & 16.2 & 1.82 & 1.73 & 1.90 & $<0.001$ \\
\hline $\begin{array}{l}\text { Insomnia } \\
\text { No }\end{array}$ & 9.4 & 9.2 & 9.5 & 1.00 & & & \\
\hline Yes & 18.7 & 17.9 & 19.5 & 2.23 & 2.11 & 2.35 & $<0.001$ \\
\hline Friends & 10.2 & 10.0 & 10.3 & 1.00 & & & \\
\hline $\begin{array}{l}\text { 1 or more } \\
\text { None }\end{array}$ & 13.0 & 11.9 & 14.1 & 1.32 & 1.19 & 1.45 & $<0.001$ \\
\hline
\end{tabular}

Family contextual factors

Being assaulted (Family members)

\begin{tabular}{|c|c|c|c|c|c|c|c|}
\hline No & 8.0 & 7.8 & 8.2 & 1.00 & & & \\
\hline Yes & 29.3 & 28.4 & 30.3 & 4.77 & 4.55 & 5.00 & $<0.001$ \\
\hline \multicolumn{8}{|c|}{ Family supervision } \\
\hline No & 13.9 & 13.6 & 14.2 & 1.00 & & & \\
\hline Yes & 7.7 & 7.4 & 7.9 & 0.51 & 0.49 & 0.54 & $<0.001$ \\
\hline \multicolumn{8}{|c|}{ Missing classes } \\
\hline No & 8.28 & 8.09 & 8.47 & 1.00 & & & \\
\hline Yes & 16.0 & 15.4 & 16.6 & 2.11 & 2.03 & 2.20 & $<0.001$ \\
\hline \multicolumn{8}{|c|}{ Living with father and/or mother } \\
\hline No & 13.3 & 12.4 & 14.2 & 1.37 & 1.26 & 1.48 & $<0.001$ \\
\hline Yes & 10.1 & 9.9 & 10.3 & 1.00 & & & \\
\hline
\end{tabular}

Contextual violence factors

Using a seatbelt

\begin{tabular}{|l|r|r|r|r|r|r|l|}
\hline Yes & 9.36 & 9.00 & 9.74 & 1.00 & & & \\
\hline No & 13.09 & 12.69 & 13.50 & 1.46 & 1.40 & 1.52 & $<0.001$ \\
\hline
\end{tabular}


Table 3. Continuation.

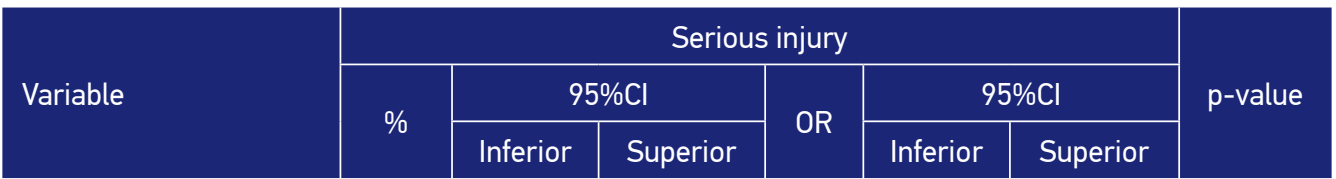

Wearing a helmet when riding a motorcycle

\begin{tabular}{c|c|c|c|c|c|c|c}
\hline Yes & 9.26 & 9.08 & 9.45 & & & & \\
\hline No & 15.78 & 15.16 & 16.41 & 1.83 & 1.75 & 1.92 & $<0.001$ \\
\hline Driving a motorized vehicle \\
\hline Yes & 16.90 & 16.30 & 17.51 & 2.13 & 2.04 & 2.23 & $<0.001$ \\
\hline No & 8.71 & 8.52 & 8.90 & 1.00 & & & \\
\hline
\end{tabular}

Being conducted in a vehicle by an inebriated person

\begin{tabular}{c|c|c|c|c|c|c|c}
\hline Yes & 19.39 & 18.66 & 20.13 & 2.49 & 2.38 & 2.61 & $<0.001$ \\
\hline No & 8.81 & 8.62 & 9.00 & 1.00 & & & \\
\hline
\end{tabular}

Insecurity in the route home-school

\begin{tabular}{|c|c|c|c|c|c|c|c}
\hline Yes & 23.8 & 22.9 & 24.8 & 3.18 & 3.02 & 3.35 & $<0.001$ \\
\hline No & 9.0 & 8.8 & 9.1 & 1.00 & & & \\
\hline
\end{tabular}

Insecurity at school

\begin{tabular}{c|c|c|c|c|c|c|c|c}
\hline Yes & 26.7 & 25.7 & 27.7 & 3.77 & 3.58 & 3.97 & $<0.001$ \\
\hline No & 8.8 & 8.6 & 9.0 & 1.00 & & & \\
\hline Being bullied & 18.3 & 17.4 & 19.2 & 2.10 & 1.97 & 2.23 & $<0.001$ \\
\hline Yes & 9.6 & 9.4 & 9.8 & 1.00 & & & \\
\hline No &
\end{tabular}

\section{Behavioral factors}

Regular tobacco

\begin{tabular}{|c|c|c|c|c|c|c|c}
\hline Yes & 26.39 & 25.19 & 27.62 & 3.45 & 3.24 & 3.68 & $<0.001$ \\
\hline No & 9.41 & 9.22 & 9.59 & 1.00 & & & \\
\hline
\end{tabular}

Regular alcohol

\begin{tabular}{c|c|c|c|c|c|c|c}
\hline Yes & 16.95 & 16.38 & 17.54 & 2.38 & 2.28 & 2.48 & $<0.001$ \\
\hline No & 7.91 & 7.72 & 8.09 & 1.00 & & & \\
\hline
\end{tabular}

Trying drugs

\begin{tabular}{c|c|c|c|c|c|c|c}
\hline Yes & 21.74 & 20.75 & 22.75 & 2.68 & 2.53 & 2.84 & $<0.001$ \\
\hline No & 9.40 & 9.22 & 9.58 & 1.00 & & & \\
\hline Sexual intercourse & 16.76 & 16.22 & 17.31 & 2.43 & 2.33 & 2.52 & $<0.001$ \\
\hline Yes & 7.66 & 7.47 & 7.86 & 1.00 & & &
\end{tabular}


Table 3. Continuation.

\begin{tabular}{|c|c|c|c|c|c|c|c|}
\hline \multirow{3}{*}{ Variable } & \multicolumn{6}{|c|}{ Serious injury } & \multirow{3}{*}{ p-value } \\
\hline & \multirow{2}{*}{$\%$} & \multicolumn{2}{|c|}{$95 \% \mathrm{Cl}$} & \multirow{2}{*}{ OR } & \multicolumn{2}{|c|}{$95 \% \mathrm{Cl}$} & \\
\hline & & Inferior & Superior & & Inferior & Superior & \\
\hline
\end{tabular}

Physical activity

\begin{tabular}{|l|l|l|l|l|l|l|l}
\hline Less than 1 hour a day & 11.0 & 10.7 & 11.3 & 1.00 & & & \\
\hline 1h or more a day & 10.7 & 10.3 & 11.2 & 0.97 & 0.93 & 1.02 & 0.238 \\
\hline
\end{tabular}

Table 4. Final variables of the model "suffering serious injury", adjusted for all variables in the model, National Adolescent School-based Health Survey. Brazil, 2012.

\begin{tabular}{|c|c|c|c|c|}
\hline \multirow{3}{*}{ Variable } & \multicolumn{3}{|c|}{ Serious injury } & \multirow{3}{*}{$\mathrm{p}$-value } \\
\hline & \multirow{2}{*}{$\mathrm{OR}$} & \multicolumn{2}{|c|}{$95 \% \mathrm{Cl}$} & \\
\hline & & Inferior & Superior & \\
\hline \multicolumn{5}{|l|}{ Gender } \\
\hline Male & 1.25 & 1.19 & 1.31 & $<0.001$ \\
\hline Femanle & 1.00 & & & \\
\hline \multicolumn{5}{|l|}{ Race } \\
\hline White & 1.00 & & & \\
\hline Black & 1.10 & 1.03 & 1.17 & 0.006 \\
\hline Yellow & 1.11 & 1.00 & 1.23 & 0.058 \\
\hline Mulatto & 1.04 & 0.99 & 1.10 & 0.087 \\
\hline Indigenous & 1.12 & 1.00 & 1.25 & 0.054 \\
\hline \multicolumn{5}{|c|}{ Currently working } \\
\hline No & 1.00 & & & \\
\hline Yes & 1.21 & 1.14 & 1.28 & $<0.001$ \\
\hline \multicolumn{5}{|l|}{ Feeling lonely } \\
\hline No & 1.00 & & & \\
\hline Yes & 1.32 & 1.25 & 1.39 & $<0.001$ \\
\hline \multicolumn{5}{|l|}{ Insomnia } \\
\hline No & 1.00 & & & \\
\hline Yes & 1.42 & 1.33 & 1.51 & $<0.001$ \\
\hline \multicolumn{5}{|c|}{ Being assaulted (Family members) } \\
\hline No & 1.00 & & & \\
\hline Yes & 2.95 & 2.80 & 3.10 & $<0.001$ \\
\hline
\end{tabular}


Table 4. Continuation.

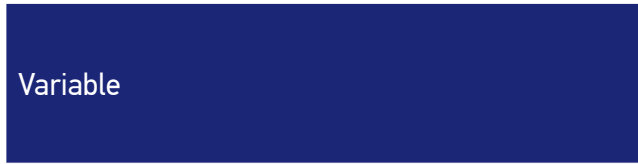

\begin{tabular}{|c|c|c|c|}
\hline \multicolumn{3}{|c|}{ Serious injury } & \multirow{3}{*}{$p$-value } \\
\hline \multirow{2}{*}{ OR } & \multicolumn{2}{|c|}{$95 \% \mathrm{Cl}$} & \\
\hline & Inferior & Superior & \\
\hline
\end{tabular}

Family supervision

\begin{tabular}{l|l}
\hline No & \\
\hline Yes & \\
\hline Missing classes & 0.7 \\
\hline
\end{tabular}

\begin{tabular}{l|}
1.00 \\
0.74
\end{tabular}

0.70

\begin{tabular}{l|l}
\hline & \\
\hline 0.77 & $<0.001$ \\
\hline
\end{tabular}

No
Yes

1.00
1.25

Living with mother and/or father

No
Yes

\begin{tabular}{|l|}
1.12 \\
1.00
\end{tabular}

1.19

(1)

\section{Using a seatbelt}

Yes
No

1.00

\begin{tabular}{l|}
\hline Wearing a helmet when riding a motorcycle \\
\hline Yes \\
\hline No
\end{tabular}

\begin{tabular}{l|l}
\hline Yes & \\
\hline No & \\
\hline Being conducted in a vehicle by an inebriated person
\end{tabular}

Yes
No

$\mid$

Insecurity in the route home-school

\begin{tabular}{c} 
Yes \\
\hline No
\end{tabular}

No

\begin{tabular}{|l|l|l|}
\hline 1.00 & & \\
\hline 1.07 & 1.02 & \\
\hline
\end{tabular}

1.12

$1.31<0.001$

Insecurity at school

\begin{tabular}{l|l}
\hline Yes & \\
\hline No & 1.6 \\
\hline Being bulled &
\end{tabular}

\begin{tabular}{|l|l|l|l|}
\hline 1.00 & & & \\
\hline 1.24 & 1.17 & 1.31 & $<0.001$ \\
\hline
\end{tabular}

\begin{tabular}{|l|l|}
1.38 \\
1.00
\end{tabular}

\begin{tabular}{|l|l|}
\hline 1.31 & \\
\hline
\end{tabular}

\begin{tabular}{l|l}
$1.45 \quad<0.001$ \\
\hline
\end{tabular}

\begin{tabular}{|l|l|l|l|}
\hline 1.43 & 1.36 & 1.51 & $<0.001$ \\
\hline 1.00 & & & \\
\hline
\end{tabular}

\begin{tabular}{l|l|l|l|l}
\hline \multicolumn{1}{l}{ Being bulled } & 1.40 & 1.31 & 1.50 & $<0.001$ \\
\hline Yes & 1.00 & & & \\
\hline No & & & & \\
\hline Regular tobacco & 1.28 & 1.19 & 1.39 & $<0.001$ \\
\hline Yes & 1.00 & & & \\
\hline No & & & &
\end{tabular}


Table 4. Continuation.

\begin{tabular}{|c|c|c|c|c|}
\hline \multirow{3}{*}{ Variable } & \multicolumn{3}{|c|}{ Serious injury } & \multirow{3}{*}{ p-value } \\
\hline & \multirow{2}{*}{ OR } & \multicolumn{2}{|c|}{$95 \% \mathrm{Cl}$} & \\
\hline & & Inferior & Superior & \\
\hline \multicolumn{5}{|c|}{ Regular alcohol } \\
\hline Yes & 1.31 & 1.25 & 1.37 & $<0.001$ \\
\hline No & 1.00 & & & \\
\hline \multicolumn{5}{|c|}{ Trying drugs } \\
\hline Yes & 1.20 & 1.12 & 1.29 & $<0.001$ \\
\hline No & 1.00 & & & \\
\hline \multicolumn{5}{|c|}{ Sexual intercourse } \\
\hline Yes & 1.29 & 1.23 & 1.36 & $<0.001$ \\
\hline No & 1.00 & & & \\
\hline
\end{tabular}

\section{DISCUSSION}

The study about injuries in adolescents with data from PeNSE indicated that 1 out of tem adolescents has been seriously injured in the past 12 months, with cuts or perforations, broken bones or dislocated joints. More severe injuries, such as brain trauma, fainting or difficulty breathing were less mentioned (about $2 \%$ ). The cause of injuries is mainly falls, which constituted almost half of the mentioned injuries. Attacks or fights, and being hit by a car by a motorized vehicle accounted for less than $10 \%$. In the analysis of associated factors, the following remained independently associated with being injured: being a male adolescent, being black, mulatto or indigenous and working. Family factors were found when bonds between members were fragile: adolescents who get injured the most are the ones who are assaulted at home, miss classes without notifying the parents, do not live with parents and have low family control. The most relevant aspects of mental health are having insomnia and feeling lonely. The factors associated with the exposure to violent situations that remained in the model were: insecurity at school and in the route home-school, being conducted by an inebriated person, driving a motorized vehicle, not wearing a seatbelt, not wearing a helmet on the motorcycle and being bullied. Among the individual risk behaviors, the following stand out: using alcohol, cigarettes, trying illicit drugs and having early sexual intercourse.

In a comparative view, the prevalence of severe injuries in adolescents in the country $(10 \%)$ is lower than in the study of Canadian Youth, which found an annual prevalence of $36 \%{ }^{15}$. In South Africa, prevalence was higher and the victimization of boys prevailed $(52 \%)$ in relation to girls $(33 \%)^{16}$. Another study on the subject in six African countries, conducted by Peltzer ${ }^{17}$, found prevalence average of $62 \%$ of injuries among adolescents 
aged 13 to 15 years old, especially the victimization of boys. The lowest prevalence in Brazil can be explained by the different cultural contexts and also by the way the question was understood by the students. PeNSE used the reference of being severely injured, which may have led to more specificity in the question. Besides, international contexts are very different, which can limit comparisons.

However, all of the studies ${ }^{15-17}$ were unanimous to identify, as is the case of Brazil, the higher prevalence among boys in relation to girls. The male gender is pointed out as a predictor of violent behaviors, be it in intentional or unintentional violent situations ${ }^{17}$. The higher prevalence of injuries among boys has been described since childhood, followed by adolescence, in teenagers and adults, leading to male overmortality due to external causes ${ }^{19,20}$. A possible explanation provided by the authors is based on cultural behaviors, in which boys are more encouraged to collective outdoors activities, such as playing soccer, riding a bike and entering violent games with weapons, while girls are mostly encouraged to playing with dolls indoors ${ }^{19,20}$. These cultural gender differences end up exposing boys to higher risks of accidents and injuries ${ }^{18}$, which is a result of the sexist culture that encourages belligerency and bellicosity, domain and taking risks ${ }^{21,22}$.

Some authors alert that researching throughout the long reminiscent period of 12 months in this age group may lead to underestimated information, and they recommend the analysis of shorter periods (1-3 months $)^{17}$; however, the same author mentions that the 12-month recollection enables to remember more severe events and lesions. Therefore, PeNSE maintained the 12 month reference, as did the GSHS.

The higher frequency of falls as the cause of injuries in this study is in accordance with what has been described by the system of Accident and Violence Surveillance (VIVA), survey that is conducted every three years in emergency units in the country. VIVA points out that falls were prevalent, followed by other accidents and, in the third position, transport accidents 5 .

In VIVA, burns are not as prevalent as in this study ${ }^{5}$. The burns were reported in $4.9 \%$ of the studies about African countries ${ }^{17}$. In Sub-Saharan Africa, burns are one of the main causes of prolonged hospitalization, deformation, impairment and death among adolescents ${ }^{23}$.

Some authors point out to the great prevalence of injuries and trauma among adolescents due to sports and recreational activities. It is the case of the studies by Peltzer $^{17}$, in Africa, and analyses in Canada ${ }^{24,25}$, as well as the investigation Scottish School Children, in Scotland ${ }^{12}$. PeNSE did not include specific questions about injuries in the practice of sports among Brazilian adolescents, therefore it is difficult to compare this aspect with the international scope. However, questions referring to the regular practice of physical exercise for one hour a day or more were analyzed. In this case, the bivariate analysis shows that such activities are protective when performed regularly, even though they did not remain in the final model. The benefits of physical activities 
for young people, in general, are associated with healthy habits and lower exposure to risks, besides the best muscle and joint conditioning ${ }^{26,27}$.

As in PeNSE, other studies ${ }^{10,17,23}$ showed association between injuries and risk behaviors, such as tobacco, alcohol and illicit drugs. An international study ${ }^{17}$ showed that drunkenness was associated with the occurrence of injuries among young people, which was confirmed by PeNSE, both in relation to the regular alcohol consumption and in relation to drunkenness (data not shown). The use of substances (tobacco, alcohol and drugs) among adolescents is a predictor of other risk behaviors, since it increases the chances of getting involved in dangerous practices, like driving a motorized vehicle and getting involved in fights, which constitutes a risk factor for injuries and wound $s^{1,10}$. Other studies indicate more distal determiners, such as poverty and social inequality, associated with injuries and wounds ${ }^{10,17,23}$. In this study, the variables related to socioeconomic level in the final model were: being mulatto, black and indigenous and the act of working. These variables are potential markers of social inequalities and can expose adolescents to living in insecure places, dislocating in insecure routes, with more exposure to violence and conflicts ${ }^{11}$. Working in this age group exposes adolescents to risk situations, with dangerous exposure to inadequate equipment and work overload, besides physical and emotional violence ${ }^{28}$, which can result in higher risks of accidents and injuries.

In the study by Peltzer ${ }^{17}$ in six African countries, the author found variations in the strength and direction of associations, according to different types of lesion. The indicator of low economic condition and loneliness were the highest predictors of injuries caused by motorized vehicles, while school evasion associated with physical struggling and depression were strong predictors of burns. In the current study, the following variables are also associated with the higher prevalence of injuries: poorer economic status, missing classes and symptoms related to poorer health status. The highest strengths of association were found when the teenager suffered family assault, lived in a violent context, felt insecure in school, had insomnia and felt lonely. All of these situations expose adolescents to vulnerable violent situations.

In this study, family supervision was the only variable with a protective effect associated with injuries. Studies have pointed out the protective role of parental supervision. Springer et al. ${ }^{29}$ reported that parental supervision plays a protective role, thus reducing violent situations and, consequently, injuries, besides risk sexual behaviors, among others.

We also emphasize the association of lesions with multiple risk behaviors6. This is the case of Peltzer's study ${ }^{17}$ with teenagers from African countries: this author found increasing gradient of injuries according to the increasing number of risk behaviors. The data in this study also confirm the weight of multiple associated risks: use of tobacco, alcohol, illicit drugs, the non-use of helmets, the non-use of the seatbelt, being conducted by an inebriated person, driving a vehicle, being bullied and having 
early sexual intercourse, which shows the complexity of policies to promote health and prevent accidents and violence in this age group.

It is also necessary to mention the limits of this study:

- It involved adolescents attending school, and not a representative sample of all teenagers in the country. The hypothesis is that adolescents outside the school scope are more vulnerable to injuries and violence;

- As aforementioned, there are studies that point out the 12-month recollection as a long period, which can eventually be in charge of a memory lapse;

- Some questions in the questionnaire may not have been understood by the students;

- Finally, this study was based on data that were collected in a cross-sectional study, which has limits to attribute causality in relation to associated factors and outcome (injuries); therefore, it is not possible to establish a temporality relationship, or the direction of causality for these associations ${ }^{30}$;

- Finally, the analysis was limited to factors included in PeNSE, therefore, other risk and protective factors cannot be measured. Consequently, the presented factors can overestimate the associations with the outcome (injuries), or even remain as associated factors to replace another factor that was not directly analyzed by the research.

\section{CONCLUSIONS}

This article is originated from the analysis of data from PeNSE, and it mentions one more type of victimization of adolescents. Even though it is frequent, it is little studied: being severely injured. Instead of thinking about this phenomenon as something autonomous and casual, it is possible to observe its association with several factors. As well as in all of the studies about violence, male young people are the most vulnerable ones.

Most studies mentioned in this article agrees at some points and, in others, they are different from the findings in this study. One relevant point of agreement is the increasing number of injuries and their association with several risk behaviors. This study brings new knowledge that reinforces the importance of an integrated work with health policies for children and adolescents. Educational programs developed by the health and educational sectors, which approach behavioral causes and determiners, instead of focusing on individual risk factors, may use a more complex reflection by observing the articulation between various situations and considering them in the work that favors the health of adolescents. 


\section{REFERENCES}

1. Organização Mundial da Saúde and United Nations Children's Fund. Child and adolescent injury prevention: a global call to action. Genebra: WHO e UNICEF; 2005.

2. Hyder AA, Puvanachandra P, Tran NH. Child and adolescent injuries: a new agenda for child health. Inj Prev 2008; 14: 67.

3. Pickett W, Molcho M, Simpson K, Janssen I, Kuntsche E, Mazur J, et al. Cross-national study of injury and social determinants in adolescents. Inj. Prev 2005; 11: 213-18.

4. Brasil. Secretaria de Vigilância em Saúde. Saúde Brasil, 2012: Uma análise de Situação de Saúde. Brasília (DF): Ministério da Saúde; 2013.

5. Malta DC, Mascarenhas MD, Bernal RT, Andrade SS, Neves AC, Melo EM, et al. Causas externas em adolescentes: atendimentos em serviços sentinelas de urgência e emergência Capitais Brasileiras 2009. Ciênc Saúde Coletiva 2012; 17(9): 2291-304.

6. Pickett W, Schmid H, Boyce WF, Simpson K, Scheidt PC, Mazur J, et al. Multiple risk behavior and injury: an international study of youth in 12 countries. Arch Pediatr Adolesc Med 2002; 156 : 786-93.

7. Soares Filho AM. Vitimização por homicídios segundo características de raça no Brasil. Rev Saúde Pública 2011; 45(4): 745-55.

8. Malta DC, Souza ER, Silva MM, Silva CS, Andreazzi MA, Crespo C et al. Vivência de violência entre escolares brasileiros: resultados da Pesquisa Nacional de Saúde do Escolar (PeNSE). Ciênc Saúde Coletiva 2010; 15(2): 3053-063.

9. Andrade SS, Yokota RT, Sá NN, Silva MM, Araújo WN, Mascarenhas MD, et al. Relação entre violência física, consumo de álcool e outras drogas e bullying entre adolescentes escolares brasileiros. Cad Saúde Pública 2012; 28(9): 1725-36.

10. Starkuniviene $S$, Zaborskis A. Links between accidents and lifestyle factors among Lithuanian school children. Medicina (Kaunas) 2005; 41: 73-80.

11. Malta DC, Porto DL, Melo FCM, Monteiro RA, Sardinha LMV, Lessa BH. Família e proteção ao uso de tabaco, álcool e drogas em adolescentes, Pesquisa Nacional de Saúde dos Escolares. Rev Bras Epidemiol 2011; 14(1): 166-77.

12. Williams JM, Wright P, Currie CE, Beattie TF. Sports related injuries in Scottish Adolescents Aged 11-15. Br J Sports Med 1998; 32(4): 291-96.
13. Brasil. Instituto Brasileiro de Geografia e Estatística. Pesquisa Nacional de Saúde do Escolar (PeNSE), 2012. Rio de Janeiro: IBGE; 2013.

14. Organização Mundial de Saúde. Social determinants of health and well-being among young people. Health behaviour in school-aged children (HBSC) study: international report from the 2009/2010 survey. Copenhagen: WHO; 2012.

15. King MA, Pickett W, King AJ. Injury in Canadian youth: a secondary analysis of the 1993-1994 Health Behaviour in School-Aged Children survey. Can J Public Health 1998; 89(6): 397-401.

16. Peltzer K. Injury and lifestyle factors among schoolaged Black and White South African children in the Limpopo Province. Afri Saf Promot 2006; 4: 15-25.

17. Peltzer K. Injury and social determinants among in-school adolescents in six African countries. Inj Prev 2008; 14(6): 381-8.

18. Hanson RF, Borntrager C, Self-Brown S, Kilpatrick DG, Saunders BE, Resnick HS, et al. Relations among Gender, Violence Exposure, and Mental Health: The National Survey of Adolescents I. Am J Orthopsychiatry 2008; 78(3): 313-21.

19. Souza ER. Masculinidade e violência no Brasil: contribuições para a reflexão no campo da saúde. Ciênc Saúde Coletiva 2005; 10(1): 59-70.

20. Malta DC, Mascarenhas MD, Silva MM, Macario EM. Perfil dos atendimentos de emergência por acidentes envolvendo crianças menores de dez anos: Brasil, 2006 a 2007. Ciênc Saúde Coletiva 2009; 14(5): 1669-679.

21. Minayo MC. Laços perigosos entre machismo e violência. Ciênc Saúde Coletiva 2005; 10(1): 18-34.

22. Minayo, MC, Constantino P. Visão ecossistêmica do homicídio. Ciênc Saúde Coletiva 2012; 17(12): 3269-278

23. Hyder AA, Kashyap KS, Fishman S, Wali SA. Review of childhood burn injuries in sub-Saharan Africa: a forgotten public health challenge. Afr Saf Promot 2004; 2(2): 43-52.

24. Pickett W, Dostaler S, Craig W, Janssen I, Simpson $\mathrm{K}$, Shelley SD, et al. Associations between risk behavior and injury and the protective roles of social environments: an analysis of 7235 Canadian school children. Inj Prev 2006; 12(2): 87-92.

25. Simpson K, Janssen I, Craig W, Pickett W. Multilevel analysis of associations between socioeconomic status injury among Canadian adolescents. J Epidemiol Community Health 2005; 59(12): 1072-77. 
26. Organização Mundial da Saúde. Handbook for guideline development. Genebra: WHO; 2009.

27. Janssen I. Physical activity guidelines for children and youth. Can J Public Health 2007; 98(2): S109-21.

28. Libório RM, Ungar M. Children's labour as a risky pathways to resilience: children's growth in contexts of poor resources. Psicol Reflex Crit 2010; 23(2): 232-42.

29. Springer AE, Sharma S, de Guardado AM, Nava FV, Kelder SH: Perceived parental monitoring and health risk behavior among public secondary school students in El Salvador. ScientificWorldJournal 2006; 6: 1810-4.

30. Rothman KJ. Epidemiology: An Introduction. New York: Oxford University Press; 2012.

Received on: 11/23/2013

Final version presented on: 02/17/2014

Accepted on: 02/20/2014 